\title{
DORA EMILIA MORA DE RETANA, A REMEMBRANCE
}

\author{
JOHN T. ATWOOD \\ Marie Selby Botanical Gardens \\ Missouri Botanical Garden
}

It was with severe regrets that I learned of the untimely death of Dora Emilia Mora de Retana. In 1985 while completing the Orchidaceae for Flora of La Selva Biological Station, I started a search for a Costa Rican with whom to collaborate on a larger project. After Robert Dressler suggested approaching Dora Emilia Mora, I visited the Universidad de Costa Rica where I found her working patiently with a student over herbarium specimens. I introduced myself forwardly proposing to collaborate on treatments of Costa Rican orchids, an approach that visibly overwhelmed this reserved Costa Rican professor. But I vowed to develop a project that would benefit her and Costa Rica as much as myself and Selby Gardens. We made a pact-I would push her and she would push me. This led over several years to mutually beneficial interactions resulting in three hundred Costa Rican orchids illustrated under Icones Plantarum Tropicarum. This activity culminated in a volume with the Field Museum of Natural History featuring subtribes Maxillariinae and Oncidiinae with help from Franco Pupulin, German Carnevali, and Joaquín García.

Dora Emilia invited me frequently to visit Lankester Gardens to share a garden visibly thriving despite dauntingly severe budget constraints. She kept a vision of Lankester Gardens not only as a tourist garden for generating revenues but as a garden dedicated to Costa Rican orchid research. The living collection of Costa Rican native orchids served as a basis for most of her descriptions and line drawings.
In later years I learned that much of her success maintaining Lankester Gardens lay in creating a positive working atmosphere for fostering students, employees, and orchid enthusiasts. Garden Manager Óscar Rodríguez would proudly show his inspired landscapes - the cactus garden, the waterfall, even a Japanese garden; Jorge Warner his propagation lab; Carlos Quirós the exquisitely curated orchid collection. Carlos, Jorge, and Oscar would soon visit Selby Gardens with Dora Emilia's help. Their enthusiastic interaction and good cheer proved them to be the best of ambassadors. Dora Emilia also introduced Costa Rican orchid society member and collaborator Joaquín García to me, a man of prodigious memory. One evening he brought me a spidery flowered maxillaria to my hotel. I identified the maxillaria as Maxillaria arachnitiflora, but the plant was odd in that it was somewhat miniature for the species. I was telling him nothing new, but for that moment the plant would remain M. arachnitiflora. Dora Emilia made several visits to Selby Gardens finalizing treatments of Costa Rican orchids, once bringing her husband Marco who volunteered his time completing the organization of the spirit collection.

Beyond her professional accomplishments, her greatest legacy is to rise above personal ambitions to foster efforts of those around her. Because of her, Lankester Gardens is blessed with a talented, imaginative, and altruistic staff continuing the tradition of fostering others, a tradition that will carry this garden to a higher level of international recognition. In a very real sense her spirit lives on. 